\title{
Analysis of Eating Behaviors (Picky Eaters), Parents Knowledge of Nutrition and Nutrition Patterns with Nutritional Status of Children Special Needs in SLB Dlanggu Mojokerto District
}

\author{
Miftakhul Muthohiroh', \\ Nurwijayanti², Yuly \\ Peristiowati $^{3}$ \\ ${ }^{1}$ Master of Public Health, \\ Institute of Health Sciences \\ Strada Indonesia \\ ${ }^{2}$ Master of Public Health, \\ Institute of Health Sciences \\ Strada Indonesia \\ ${ }^{3}$ Master of Public Health, \\ Institute of Health Sciences \\ Strada Indonesia \\ Email: \\ miftaqu190@gmail.com
}

Received : May $6^{\text {th }} 2021$

Accepted : May $10^{\text {th }} 2021$

Published : May 20 2021

\begin{abstract}
Children with special needs are required to be able to live independently, adapt and socialize with normal people so that it can escape from the dependence of others. This study aims to study the relationship between nutritional status, nutritional knowledge, and parenting styles of parents with picky eaters in children with special needs in special schools in Mojokerto. The design of this research is analytic observational with a quantitative approach. The population is all students of the Special School in 3 schools in Mojokerto, as many as 186 students. Samples were obtained from some of the SLB students in 3 schools in Mojokerto with a total of 117 respondents. The sampling technique used accidental sampling. The results of this study, most of them experienced the eating behavior of picky eaters in the low category, namely 95 respondents $(81.2 \%)$, mothers who had sufficient knowledge of nutrition, namely 70 respondents $(59.8 \%)$, parents who applied parenting styles. dominant instrumental feeding (IF) is 38 respondents $(32.5 \%)$, respondents with normal nutritional status are 54 respondents $(46.2 \%)$, picky eater variables and knowledge variables have an effect on nutritional status. Parents must always increase knowledge about how to select, process and serve nutritious food to children, because nutritious food does not have to be expensive and the school must increase its role as a provider of education not only for their children but for parents about nutrition.
\end{abstract}

Keywords: Eating behaviors, nutrition, knowledge, parenting style 
Analysis of Eating Behaviors (Picky Eaters).....

This is an open-acces article distributed under the terms of the Creative Commons AttributionShareAlike 4.0 International License.

\section{INTRODUCTION}

The growth and development of children is influenced by various factors, one of which is adequate nutritional intake. Children need foods that are in accordance with balanced nutrition to achieve optimal nutritional status. Nutritional status is a condition of a person's body health that reflects food consumption in a relatively long period of time. Nutritional status is influenced by food consumption, physical activity, and a person's medical history. Adequate nutrition in children is needed for physical growth, brain development, and a high degree of health. Low food consumption results in inadequate nutrient intake, leading to malnutrition. Picky eating behavior is an eating problem that often occurs in school-age children, generally children are picky eaters and refuse to eat or try new, unfamiliar foods. Many factors influence picky eating behavior, one of which is the practice of parenting applied by parents.

Food parenting is influenced by the nutritional knowledge of the parents. Mothers who have good nutrition knowledge are more likely to be able to apply their nutritional knowledge in their daily life, so that this will affect the mother's diet. Children tend to choose only the food they like to be consumed, not paying attention to nutritional, health and economic factors. Children's preferences for food groups are influenced by various factors, including individual characteristics including gender and age, parenting habits, perceptions of food taste, and the environment. Picky eaters often limit the type and amount of food consumption (generally vegetables), have a strong liking for certain foods, and are unwilling to try new foods.

Parents and teachers play an important role in the business improve children's nutrition. At elementary grade age, children experience growth growth very rapidly so that it requires good nutritional intake so that the growth and development of the body is balanced, healthy and intelligent. An overview of children's health development can be seen from the status nutrition. Nutritional status is a description of the balance between food intake and a person's nutritional needs. Nutrition is part of the process of child development, so that the fulfillment of proper nutrition also determines the quality of children's growth and development (Ministry of Health, 2013). Nutritional status can be said to be good if the nutritional intake is in accordance with individual needs. The fulfillment of nutrition is adjusted to the balanced nutrition guidelines that have been introduced by the Ministry of Health. The principle of balanced nutrition consists of 4 main pillars, namely 1) consuming a variety of foods, 2) getting used to a clean life, 3) engaging in physical activity, 4) monitoring body weight regularly to maintain a normal body weight.

Children with special needs are required to be able to live independently, adapt and socialize with normal people so that it can escape from the dependence of others. But lack of attention from parents often lead to deviant treatment in children. Treatment and inappropriate attention will take many forms wrong child care. As a result, children cannot live independently, they can inhibits the formation of positive social attitudes, and lacks the courage of the child to take an action, both physical and non-physical and affect the ability to move.

According to the results of research conducted by the Center for Disease Control and Prevention in the United States in March (2013), it was reported that the prevalence of children with special needs increased to 1:50 in the past year. This happens not only in developed countries such as Britain, Australia, Germany and America but also in developing countries. Children with special needs are at risk of malnutrition due to several factors, including strict diet therapy, food behavior disorders (picky eaters) such as difficulty accepting new food and very slow chewing movements, limited food intake, parental nutritional knowledge and the effects of drugs - medicine. With the provision of a gluten and casein free diet, children with autism will be limited in consuming their daily food so that the food consumed is not varied and the macro and micro nutrients that should be available are also 
reduced so that it will have an impact on the nutritional status of the child (Rahayu, 2016). The incidence of picky eating continues to increase. Research in San Francisco in 2014 found the highest incidence of picky eating in children over 2 years of age as much as $13-22 \% .8$ Previous research in Indonesia showed a high incidence of picky eating. In 2012 in Palembang and Bekasi, it was found that $59.3 \%$ and $70.5 \%$ of children had picky eating, respectively. Research in Riau in 2015 found that $35.4 \%$ of children experienced picky eating. Research in Semarang found $60.3 \%$ of children experience picky eating.

Mentally retarded children, apart from having intellectual limitations, also have problems in daily behavior. Mentally retarded children have difficulty maintaining their health and diet, so they are vulnerable to diseases that threaten their health. Good nutrition is obtained by providing nutritional intake in accordance with the required amount according to the RDA. Mentally retarded children with good nutritional status, are able to maintain health. The nutritional status of mentally retarded children also affects their daily activities at home or at school. A good nutritional status can make it easier for mentally retarded children to do physical activities that can support health. Maintained health can make it easier for mentors or mentors of mentally retarded children to provide directions or commands both in lessons or when exercising. Undernutrition and excess status can pose a risk of dangerous diseases.

Initial observations were carried out at one of the Special Schools in Mojokerto Regency with 15 respondents as parents of mentally retarded students. The age of the respondent's mentally disabled children varied between 6-18 years. The results of the observation stated that only 7 respondents filled in complete data on children's BMI measurements. Based on these 7 respondents, it is known that 2 children of the respondent have a good nutritional status, 1 child has a mild level of nutrition, and 4 children have a severe malnutrition status. The BMI threshold category is taken from the BMI Category for Indonesia. The principal of this special school when interviewed said that the educational level of mentally retarded children varies from SDLB to high school and varies in severity.

This research generally aims to study the relationship / relationship between nutritional status, nutritional knowledge and parenting styles of parents with eating behavior disorders (picky eaters) in children with special needs in special schools in Mojokerto.

\section{MATERIALS AND METHODS}

The design of this research is analytic observational with a quantitative approach. The population is all students of special schools in 3 schools in Mojokerto, namely 186 students. Samples were obtained from some of the SLB students in 3 schools in Mojokerto with a total of 117 respondents. The sampling technique used Accidental sampling. The data collection instrument used a questionnaire. The independent variables were eating behavior disorders, parents' nutritional knowledge and parenting styles. While the dependent variable is the nutritional status of children with special needs. The statistical analysis used was ordinal regression statistical test. The implementation of this research began in March - December 2019.

\section{RESULTS}

Table 1. Distribution of respondent characteristics

\begin{tabular}{lll}
\hline Characteristics & $\mathbf{N}$ & $\mathbf{\%}$ \\
\hline Mother's last education & & \\
Basic & 3 & 2,6 \\
Intermediate & 37 & 31,6 \\
$\quad$ High & 77 & 65,8 \\
\hline Children's age & & \\
$\quad$ Children & 69 & 59 \\
Early teens & 38 & 32,5
\end{tabular}




\begin{tabular}{|c|c|c|}
\hline Late teens & 10 & 8,5 \\
\hline \multicolumn{3}{|l|}{ Gender of child } \\
\hline Man & 57 & 48,7 \\
\hline Female & 60 & 51,3 \\
\hline \multicolumn{3}{|c|}{ Children's education in special schools } \\
\hline Primary school & 83 & 71 \\
\hline Junior High & 24 & 20,5 \\
\hline High school & 10 & 8,5 \\
\hline \multicolumn{3}{|l|}{ Type of disability } \\
\hline Tuna daksa & 10 & 8,5 \\
\hline Mentally disabled & 34 & 29,1 \\
\hline Tunneled tuna & 10 & 8,5 \\
\hline Deaf & 24 & 20,5 \\
\hline Speech impaired & 39 & 33,3 \\
\hline \multicolumn{3}{|l|}{ Picky eaters } \\
\hline High & 0 & 0 \\
\hline Moderate & 22 & 18,8 \\
\hline Low & 95 & 81,2 \\
\hline \multicolumn{3}{|c|}{ Mother's knowledge about nutrition } \\
\hline Less & 28 & 23,9 \\
\hline Enough & 70 & 59,8 \\
\hline Well & 19 & 16,2 \\
\hline \multicolumn{3}{|l|}{ Nutritional parenting } \\
\hline Control Over Eating (CEO) & 24 & 20,5 \\
\hline Emotional Feeding (EF) & 28 & 23,9 \\
\hline Encouragement To Eat (EE) & 27 & 23,1 \\
\hline Instrumental Feeding (IF) & 38 & 32,5 \\
\hline \multicolumn{3}{|l|}{ Child nutritional status } \\
\hline Thin & 6 & 5,1 \\
\hline Normal & 54 & 46,2 \\
\hline Obesity & 26 & 22,2 \\
\hline Obesity & 31 & 26,5 \\
\hline Total & 117 & 100 \\
\hline
\end{tabular}

\section{Data analysis}

Table 2. Simultaneous test results ordinal regression simultaneous correlation/variable picky eaters (X1), maternal knowledge about nutrition (X2), nutritional parenting (X3) with nutritional status (Y)

\begin{tabular}{ccccc}
\hline Model & $\mathbf{- 2 ~ L o g ~ L i k e l i h o o d ~}$ & Chi-Square & df & Sig. \\
\hline Intercept Only & 127,111 & & & \\
Final & 105,984 & 21,126 & 6 &, 002 \\
\hline
\end{tabular}

Based on the results of the analysis according to the fitting information model, the chisquare value was 21.126 with a significance value of $0.002<0.05$, which means that all variables, namely the picky eater (X1), knowledge of nutrition (X2) and nutritional parenting (x3) have a significant effect together. -equal to the nutritional status variable (Y). This value is reinforced by the goodness-of-fit results as shown below. 
Table 3. Goodness-of-Fit

\begin{tabular}{cccc}
\hline & Chi-Square & df & Sig. \\
\hline Pearson & 54,538 & 54 &, 454 \\
Deviance & 48,555 & 54 &, 684 \\
\hline
\end{tabular}

The goodness of fit table shows the suitability test of the model with the data. The Pearson value was 54.583 with a significance of $0.454(>0.05)$ and a deviance of 48.555 with a significance of $0.684(>0.05)$. This means that the model according to empirical data or the model is suitable for use.

Table 4. Results of partial regression ordinal regression, partial correlation of picky eater variables (X1), maternal knowledge about nutrition (X2), nutritional parenting (X3) with nutritional status (Y1)

\begin{tabular}{|c|c|c|c|c|c|c|c|c|}
\hline & & \multirow[b]{2}{*}{$\begin{array}{l}\text { Estimat } \\
\mathrm{e}\end{array}$} & \multirow[b]{2}{*}{$\begin{array}{l}\text { Std. } \\
\text { Error }\end{array}$} & \multirow[b]{2}{*}{ Wald } & \multirow[b]{2}{*}{$\begin{array}{l}d \\
f\end{array}$} & \multirow[b]{2}{*}{ Sig. } & \multicolumn{2}{|c|}{$\begin{array}{l}\text { 95\% Confidence } \\
\text { Interval }\end{array}$} \\
\hline & & & & & & & $\begin{array}{l}\text { Lower } \\
\text { Bound }\end{array}$ & $\begin{array}{c}\text { Upper } \\
\text { Boun } \\
\mathrm{d}\end{array}$ \\
\hline \multirow[t]{3}{*}{ Threshold } & [nutritional status $=1,00]$ & $-3,507$ & ,693 & $\begin{array}{c}25,58 \\
6\end{array}$ & 1 &, 000 & $-4,865$ & $-2,148$ \\
\hline & [nutritional status $=2,00]$ &,- 287 &, 542 & ,281 & 1 & ,596 & $-1,349$ &, 774 \\
\hline & [nutritional status $=3,00]$ & ,850 &, 549 & 2,396 & 1 & ,122 &,- 226 & 1,927 \\
\hline \multirow[t]{8}{*}{ Location } & $\begin{array}{l}{[\text { Picky_Eater }=2,00]} \\
{[\text { Picky_Eater }=3,00]}\end{array}$ & $\begin{array}{c}-1,336 \\
0^{\mathrm{a}}\end{array}$ &, 511 & 6,848 & $\begin{array}{l}1 \\
0\end{array}$ & ,009 & $-2,337$ &,- 335 \\
\hline & {$[$ knowledge $=1,00]$} & 1,280 &, 583 & 4,817 & 1 & ,028 & ,137 & 2,422 \\
\hline & {$[$ knowledge $=2,00]$} &,- 213 & 499 &, 182 & 1 & 670 & $-1,191$ &, 765 \\
\hline & {$[$ knowledge $=3,00]$} & $0^{\mathrm{a}}$ & & & 0 & & & \\
\hline & [parenting_nutritional $=1,00$ ] &,- 428 &, 506 & ,714 & 1 & ,398 & $-1,420$ & ,565 \\
\hline & [parenting_nutritional $=2,00]$ &,- 501 &, 490 & 1,046 & 1 & ,306 & $-1,461$ & ,459 \\
\hline & [parenting_nutritional $=3,00$ ] & 011 & ,491 & ,001 & 1 & ,982 &,- 952 & ,974 \\
\hline & [parenting_nutritional $=4,00]$ & $0^{\mathrm{a}}$ & & & 0 & & & \\
\hline
\end{tabular}

The results of the ordinal regression analysis show the probability values as follows:

1) The picky eater variable (X1) obtained a p-value of $0.009<\alpha=0.05$, so that $\mathrm{H} 0$ is rejected and $\mathrm{H} 1$ is accepted. This means that the picky eater variable affects the nutritional status of special schools in Mojokerto.

2) The variable of mother's knowledge about nutrition (X2) obtained a p-value of $0.028<\alpha=0.05$, so that $\mathrm{H} 0$ is rejected and $\mathrm{H} 1$ is accepted. This means that the variable knowledge of mothers about nutrition affects nutritional status in special schools in Mojokerto.

3) The nutritional parenting variable (X3) obtained a p-value of $0.398>\alpha=0.05$, so that $\mathrm{H} 0$ is accepted and $\mathrm{H} 1$ is rejected. This means that the variable of nutritional parenting has no effect on nutritional status in special schools in Mojokerto.

\section{DISCUSSION}

\section{Picky Eater at SLB Mojokerto}

Based on table 1, it shows that of the 117 respondents most of them experienced picky eaters eating behavior in the low category, namely 95 respondents $(81.2 \%)$.

Picky eaters are children who have difficulty eating or only like certain types of food. Difficulty eating (pickyeater) is the behavior of the child refusing to eat or refusing to eat, or having difficulty consuming food or drinks of the type and amount according to age physiologically (naturally and 
naturally), starting from opening his mouth without coercion, chewing, swallowing, until absorbed in digestion properly without coercion and without giving certain vitamins and drugs.

The results showed that the picky eater eating behavior in children was classified as low, this means that the respondents did not experience too much picky eater. The findings in research that usually cause difficulties for mothers is to provide foods in the form of vegetables, especially if they are classified as new vegetables, so that the mother has to persuade her several times so that the child wants to eat these vegetables. There are some that work and there are some that fail. However, on the whole, respondents in the research location did not really experience the problem of eating picky eaters.

\section{Maternal knowledge about nutrition at SLB Mojokerto}

Based on table 1, it shows that from 117 respondents, the largest data obtained were mothers who had sufficient knowledge of nutrition, namely 70 respondents $(59.8 \%)$.

The results showed that many of the research respondents already knew the nutrition in the sufficient category. However, what should be noted is that the knowledge about nutrition that is known to the respondents is still only basics or needs to be known in general by the general public. There are also mothers who still have less knowledge. This is more due to the fact that they rarely receive information about nutrition, they rarely read information from mass media or internet media. Those with less knowledge usually receive occasional information from health workers but usually forget it again. Therefore it is important to actively provide information from all sources such as health workers, health cadres who work together regularly with schools to provide information about children's health, especially the provision of balanced nutrition.

\section{Nutritional parenting in Mojokerto special school}

Based on table 1, it shows that of the 117 respondents, the largest data obtained was that parents applied dominant instrumental feeding (IF) parenting, namely 38 respondents $(32.5 \%)$.

The parenting style that is most widely applied by research respondents is instrumental feeding (IF), namely the behavior or the way parents give appreciation to children by providing food if they show behavior ordered by the parents. This award is given by parents in the form of praise to the child, giving his favorite food and obeying the child's wishes about what to eat. However, after all, giving food to children with disabilities is not as easy as feeding normal children. It takes extra patience and energy to provide food with sometimes changing parenting styles. The economic condition of the parents remains the main factor in the provision of food to children, the purchasing power of respondents for nutritious foods is different, some are able, some are mediocre, some are deficient. In addition, the ability to process food factors is also different. There are parents who are able to cook according to the taste of their children, some are not.

\section{Nutritional status at SLB Mojokerto}

Based on table 1 shows that of the 117 respondents, the largest data obtained were respondents with normal nutritional status, namely 54 respondents $(46.2 \%)$.

The nutritional status of respondents who are children with disabilities have an average nutritional status. However, it should be noted that there are still children who are underweight and many are overweight and obese. Many children who experience underweight nutritional status are due to a lack of nutritional intake. The lack of nutritional intake is mostly due to mothers who do not provide sufficient nutritious food for their children because they cannot afford to buy it, because some mothers do not work or only care for their children everyday so that they have less income. Children who are overweight and obese, according to their parents, really like to eat, they eat anything at home that can be eaten and often eat food from snacks in stalls and instant food such as instant noodles. 


\section{Effect of picky eaters on nutritional status}

Based on table 1, it shows that of the 117 respondents, the most data respondents who experienced picky eaters were in the low category and had normal nutritional status, namely 39 respondents $(33.3 \%)$ and the least were respondents who had moderate picky eaters and were obese, namely 1 respondent $(0.9 \%)$.

The results showed that picky eaters had an effect on nutritional status where children who were not picky eaters had higher nutritional value. Picky eater deals with the process of intake of children's nutritional intake. Children who experience picky eaters will find it difficult to receive nutritional intake so they are at risk of lack of nutritional intake. Children who eat or are picky eaters have lower nutritional status scores. Children who are not picky eaters will easily eat whatever their parents provide, give others or find their own food. If this is not controlled, the child will become overweight or obese, it will interfere with the development of other children. Because there are many disease threats that await obese sufferers, besides that, their movement is also increasingly hampered.

\section{Effect of maternal knowledge about nutrition with nutritional status}

Based on table 1, it shows that of the 117 respondents, the most data were respondents who had sufficient knowledge about nutrition and their children had normal nutritional status, namely 37 people $(31.6 \%)$ and none $(0 \%)$ of mothers had good knowledge of nutrition and their children. have a thin nutritional status.

Mother's knowledge about nutrition is very important for the nutritional status of children. Mothers who have good knowledge will be able to choose the types of food that have good nutritional value in children. After being able to choose, mothers must also have knowledge of how to process foods that are good or that arouse children's appetites and also have control over their daily food intake. So the mother's knowledge must be from choosing to serving food to children in sufficient portions. Mothers who do not have sufficient knowledge or only half-heartedly will have provided good and sufficient nutritional intake.

\section{Effect of nutritional parenting with nutritional status}

Based on table 1, it shows that of the 117 respondents the most data were mothers who applied instrumental feeding (IF) and their children had normal nutritional status, namely 20 respondents $(17.1 \%)$ and the least data were mothers who applied Encouragement to Eat (EE) parenting. ) and their children have a malnutrition status as much as 1 person $(0.9 \%)$. The results of cross tabulation are reinforced by the results of ordinal regression where the nutritional parenting variable (X3) obtained a p-value of $0.398>\alpha=0.05$, so that $\mathrm{H} 0$ is accepted and $\mathrm{H} 1$ is rejected. This means that the variable of nutritional parenting has no effect on nutritional status in special schools in Mojokerto.

Nutritional parenting is food intake in order to support the physical and biological growth of toddlers in a precise and balanced manner (Eveline \& Nanang D, 2010). Parenting patterns are in the form of behavior of mothers or other caregivers in terms of their closeness to children, providing food, caring for, hygiene, giving affection and so on. All of them relate to the condition of the mother, especially in health, nutritional status, general education, knowledge and skills about good childcare, roles in the family or community, the nature of daily work, family customs, community and so on from the mother or child caregiver.

Nutritional parenting is a strong factor in children's nutritional status. Improper nutrition can lead to malnutrition or excess nutrition, considering that the children who are respondents are children with disabilities, they are very dependent on parents for nutritional fulfillment problems. However, the backgrounds of different parents mean that each also gets different nutritional parenting styles.

\section{Effect of picky eaters, Mother's knowledge of nutrition, nutrition parenting (X3) with nutritional status}


Based on the results of the analysis according to the fitting information model, the chi-square value of 21.126 with a significance value of $0.002<0.05$, which means that all variables, namely the picky eater (X1), knowledge of nutrition (X2) and nutritional parenting (x3) have a significant effect together. -equal to the nutritional status variable (Y).

The results of the study showed that all variables had a simultaneous or simultaneous influence on the nutritional status of children. Picky eater is a direct factor in children's nutritional intake, knowledge factor is an indirect factor in nutritional status where this knowledge will affect nutritional parenting which is also a direct factor on children's nutritional status, this is because children with disabilities are almost entirely dependent on parents for fulfillment. their nutrition.

The school and the Puskesmas must collaborate on a regular basis in providing education and direct assistance such as nutritious food every week.

\section{CONCLUSION}

1. Most of them experienced picky eater eating behavior in the low category, as many as 95 respondents $(81.2 \%)$.

2. Most were mothers who had sufficient knowledge of nutrition, as many as 70 respondents $(59.8 \%)$.

3. Most of the parents adopted the dominant instrumental feeding (IF) parenting, as many as 38 respondents $(32.5 \%)$.

4. Most of the respondents with normal nutritional status were 54 respondents (46.2\%).

5. Picky eater variable affects nutritional status in special schools in Mojokerto.

6. Maternal knowledge variables about nutrition affect nutritional status in special schools in Mojokerto

7. Nutritional parenting variables did not affect nutritional status in special schools in Mojokerto

8. All variables, namely picky eaters (X1), knowledge about nutrition (X2) and nutrition parenting (x3) have a significant effect on the variable nutritional status (Y).

\section{ACKNOWLEDGMENTS}

The researcher would like to thank the Special School in 3 schools in Mojokerto who have given permission to research. Thank you to all respondents who helped with data collection.

\section{CONFLICT OF INTEREST}

The author declares that no conflict of interest in this research.

\section{REFERENCES}

Mardini KW. 2014. Faktor Resiko Pendek Pada Anak. Bali : Biomedik Univesitas Udayana

Munawaroh, Siti. 2015. Pola Asuh Mempengaruhi Status Gizi Balita. Jurnal Keperawatan Volume 6 Nomer 1

Notoatmodjo, Soekidjo. 2010. Promosi Kesehatan dan Perilaku Kesehatan. Jakarta: Rineka Cipta

Proverawati, A., \& Kusuma, E. W. 2011. Ilmu Gizi untuk Keperawatan dan Gizi Kesehatan . Yogyakarta: Nuha Medika

Riyadi H. 2013. Metode Penilaian Status Gizi secara Antropometri. Bogor : Fakultas Ekologi Manusia. Institut Pertanian Bogor.

Supariasa BB, Ibnu Fajar. 2009. Penilaian Status Gizi. Jakarta: EGC.

Syafiq, A. 2012. Gizi dan Kesehatan Masyarakat. Edisi ke-7. Jakarta : Raja Grapindo Persada

Syafiq, Ahmad. 2012. Tinjauan Atas Kesehatan dan Gizi Anak usia dini. Jakarta : BAPPENAS RI

WHO. 2010. Stunting Policy Brief. WHO Press: Geneva

Wirjatmadi, B. 2012. Peranan Gizi Dalam Siklus Kehidupan. Jakarta : Kencana Pustaka.

World Health Organization. World Health Statistics 2017. Geneva: WHO Press. 